\title{
Review \\ Clinical review: Therapy for refractory intracranial hypertension in ischaemic stroke
}

\author{
Eric Jüttler ${ }^{1}$, Peter D Schellinger ${ }^{2}$, Alfred Aschoff ${ }^{3}$, Klaus Zweckberger ${ }^{3}$, Andreas Unterberg $^{3}$ \\ and Werner Hacke ${ }^{1}$
}

\author{
${ }^{1}$ Department of Neurology, University of Heidelberg, Im Neuenheimer Feld 400, D-69120 Heidelberg, Germany \\ 2Department of Neurology, University of Erlangen, Schwabachanlage 6, D-91054 Erlangen, Germany \\ ${ }^{3}$ Department of Neurosurgery, University of Heidelberg, Im Neuenheimer Feld 400, D-69120 Heidelberg, Germany
}

Corresponding author: Eric Jüttler, eric.juettler@med.uni-heidelberg.de

Published: 25 October 2007

This article is online at http://ccforum.com/content/11/5/231

(c) 2007 BioMed Central Ltd
Critical Care 2007, 11:231 (doi:10.1186/cc6087)

\begin{abstract}
The treatment of patients with large hemispheric ischaemic stroke accompanied by massive space-occupying oedema represents one of the major unsolved problems in neurocritical care medicine. Despite maximum intensive care, the prognosis of these patients is poor, with case fatality rates as high as $80 \%$. Therefore, the term 'malignant brain infarction' was coined. Because conservative treatment strategies to limit brain tissue shift almost consistently fail, these massive infarctions often are regarded as an untreatable disease. The introduction of decompressive surgery (hemicraniectomy) has completely changed this point of view, suggesting that mortality rates may be reduced to approximately $20 \%$. However, critics have always argued that the reduction in mortality may be outweighed by an accompanying increase in severe disability. Due to the lack of conclusive evidence of efficacy from randomised trials, controversy over the benefit of these treatment strategies remained, leading to large regional differences in the application of this procedure. Meanwhile, data from randomised trials confirm the results of former observational studies, demonstrating that hemicraniectomy not only significantly reduces mortality but also significantly improves clinical outcome without increasing the number of completely dependent patients. Hypothermia is another promising treatment option but still needs evidence of efficacy from randomised controlled trials before it may be recommended for clinical routine use. This review gives the reader an integrated view of the current status of treatment options in massive hemispheric brain infarction, based on the available data of clinical trials, including the most recent data from randomised trials published in 2007 .
\end{abstract}

\section{Introduction}

Subtotal or complete middle cerebral artery (MCA) territory infarctions, including the basal ganglia, occasionally with additional infarction of the anterior cerebral artery (ACA) or the posterior cerebral artery (PCA) or both, are found in $1 \%$ to $10 \%$ of patients with supratentorial infarcts [1-3]. They are commonly associated with serious brain swelling, which usually manifests itself between the second and the fifth day after stroke onset [1-8]. Space-occupying cerebral infarction is a life-threatening event. Mass effect leads to the destruction of formerly healthy brain tissue and, in severe cases, to extensive brain tissue shifts resulting in transtentorial or uncal herniation and brain death $[3,6,9]$. These complications are responsible for the rapid neurologic deterioration seen in such patients [1]. In intensive care-based prospective series, the case fatality rate of these patients was approximately $78 \%$ despite maximum medical therapy $[3,10,11]$. For these catastrophic cerebral infarcts, the term 'malignant infarction' was coined by Hacke and colleagues [3] in 1996.

Clinically, these patients present with dense hemiplegia, head and eye deviation, and multimodal hemineglect; global aphasia coexists when the dominant hemisphere is involved $[2,3]$. The National Institutes of Health Stroke Scale score is typically greater than 20 when the dominant hemisphere is involved and greater than 15 when the nondominant hemisphere is involved $[12,13]$. They show a rapidly progressive deterioration of consciousness over the first 24 to 48 hours and frequently a reduced ventilatory drive [3]. Neuroimaging typically shows definite infarction of at least two thirds of the MCA territory, including the basal ganglia, with or without additional infarction of the ipsilateral ACA or the PCA territories, or an infarct volume of greater than $145 \mathrm{~cm}^{3}$ using diffusion-weighted imaging [14-18]. Because of an increasing number of young patients suffering from brain infarction (a group of patients at particular danger of malignant infarction),

$\mathrm{ACA}=$ anterior cerebral artery; $\mathrm{ARR}=$ absolute risk reduction; $\mathrm{CPP}=$ cerebral perfusion pressure; $\mathrm{DECIMAL}=\mathrm{DE}$ compressive Craniectomy In MALignant middle cerebral artery infarcts; DESTINY = DEcompressive Surgery for the Treatment of malignant INfarction of the middle cerebral arterY; GCS = Glasgow Coma Scale; HAMLET = Hemicraniectomy After Middle cerebral artery infarction with Life-threatening Edema Trial; ICP = intracranial pressure; $\mathrm{MCA}=$ middle cerebral artery; $\mathrm{mRS}=$ modified Rankin scale; $\mathrm{PaCO}_{2}=$ arterial partial pressure of carbon dioxide; $\mathrm{PCA}=$ posterior cerebral artery; $\mathrm{pCO}_{2}=$ partial pressure of carbon dioxide; $\mathrm{pO}_{2}=$ partial pressure of oxygen; THAM $=$ Tris-hydroxy-methyl-aminomethane. 
finding an optimal treatment solution has made this a most urgent topic in neurointensive care medicine during the last decade.

\section{Treatment options}

\section{Conservative treatment}

\subsection{General stroke treatment}

As far as blood pressure, blood glucose level, body core temperature control, fluid and nutrition management, and prophylaxis of deep venous thrombosis are concerned, patients with malignant MCA infarctions are treated according to the current guidelines of general ischaemic stroke treatment [19-21]. There are some modifications:

Induced hypertension may be useful in case of haemodynamic relevant vessel stenoses or to maintain critical perfusion in the presence of radiologically confirmed penumbra [22]. However, there are no controlled trials to confirm this, and available data are contradictory $[23,24]$. In a prospective trial in patients with malignant MCA infarction, induced hypertension increased cerebral perfusion pressure (CPP) without a relevant increase of intracranial pressure (ICP) [25]. An exception is made in patients receiving decompressive surgery. In these cases, systolic blood pressure during the postoperative phase of the first 8 hours after surgery is kept at 140 to $160 \mathrm{~mm} \mathrm{Hg}$ to avoid severe bleeding [26].

Previous recommendations of elevation of the head of $30^{\circ}$ in patients with malignant MCA infarction should not generally be followed. The idea is that head elevation may improve venous drainage. Furthermore, an upright body positioning reduces the risk of nosocomial infections [27-29]. In fact, although elevation of the head may decrease ICP, the effect on CPP is less predictable. In several studies, head elevation increased CPP [30-32], decreased CPP [33,34], or left CPP unaltered [35-37]. Most of these studies investigated patients with traumatic brain injury or subarachnoid haemorrhage. However, in large ischaemic stroke, different pathophysiological aspects such as the possibility of salvaging tissue in the ischaemic penumbra must be taken into consideration. Only one study has investigated the effect of body positioning in patients with large hemispheric ischaemic stroke [34]. According to the results, a plane positioning of the head is recommended. Only in case of considerable increases in ICP or in patients at high risk of nosocomial infections, a moderate elevation of the head of $15^{\circ}$ to $30^{\circ}$ is recommended, always depending on the CPP [34]. Any form of compression of the jugular veins should be avoided.

As soon as ventilatory drive is depressed, airway protection becomes paramount, necessitating intubation, ventilation, and sedation. Patients should be intubated at a Glasgow Coma Scale (GCS) score of lower than 8, or if there are any signs of respiratory insufficiency (partial pressure of oxygen $\left[\mathrm{pO}_{2}\right]$ of less than $60 \mathrm{~mm} \mathrm{Hg}$ or partial pressure of carbon dioxide $\left[\mathrm{pCO}_{2}\right]$ of greater than $48 \mathrm{~mm} \mathrm{Hg}$ ) or signs of ineffective swallowing or cough reflexes, or if the airway is compromised [38]. Deep sedation is recommended to avoid uncontrolled increases of ICP $[27,28]$. The following parameters should be targeted: $\mathrm{PaO}_{2}$ (arterial partial pressure of oxygen) above 75 $\mathrm{mm} \mathrm{Hg}$ and arterial partial pressure of carbon dioxide $\left(\mathrm{PaCO}_{2}\right)$ of 36 to $44 \mathrm{~mm} \mathrm{Hg}$. In case of raised ICP, the ventilation mode should be changed: Minute ventilation should be adjusted to maintain $\mathrm{PaCO} 2$ levels between 35 and $40 \mathrm{~mm} \mathrm{Hg}$ and $\mathrm{pO}_{2}$ above $100 \mathrm{~mm} \mathrm{Hg}$. A minimum of $5 \mathrm{~cm} \mathrm{H} 2 \mathrm{O}$ of positive end-expiratory pressure and a minimum FiO2 (fraction of inspired oxygen) to maintain $\mathrm{SaO} 2$ (saturation of oxygen [arterial blood]) above $90 \%$ are advocated $[26,27,39,40]$.

All patients with malignant MCA infarction should be treated at an experienced neurointensive care unit [26-28]. The treatment options listed below can be effective only with detailed haemodynamic, neuroimaging, and invasive multimodal monitoring tools (at least ICP and CPP, measurement in the ipsilateral side), the possibility of rapid interventions, and an experienced neurosurgical department in house. CPP measurement and repeated neuroimaging are strongly recommended. ICP alone is not a good parameter for neurologic deterioration and does not monitor brain displacement [6].

\subsection{Anti-oedema therapy}

The use of osmotic agents is based on the idea of creating an osmotic pressure gradient over the semipermeable membrane of the blood-brain barrier and thereby drawing interstitial and intracellular water from the swollen brain into intravascular spaces. For the treatment of brain oedema after stroke, mannitol, glycerol, hydroxyethyl starch, and hypertonic saline are currently the most widely used [41]. According to the current guidelines, osmotherapy should be started in the case of increases of ICP [19-21]. The use of mannitol $(100 \mathrm{ml}$ of $20 \%$ solution or 0.5 to $1.0 \mathrm{~g} / \mathrm{kg}$ every 4 to 6 hours; maximum daily dose, $2.5 \mathrm{~g} / \mathrm{kg}$ ), glycerol $(250 \mathrm{ml}$ of $10 \%$ solution, four times per day), or hydroxyethyl starch (6\% hetastarch in $0.9 \%$ $\mathrm{NaCl}$ injection, 100 to $250 \mathrm{ml}$ every 8 hours; maximum daily dose, $750 \mathrm{ml}$ ) is recommended. Onset of action of these substances is within minutes, and the duration is as long as 4 to 8 hours $[27,28,41,42]$. In repeated use, dosage depends on serum osmolality, which should be targeted at 315 to $320 \mathrm{mOsmol}$. Hyperosmolar saline solutions $(10 \% \mathrm{NaCl}$, $75 \mathrm{ml}$, repeated doses) may be used as an alternative. The advantage of hyperosmolar saline is that it is actively excluded from an intact blood-brain barrier [43]. Another advantage is that it can be combined with mannitol because it counteracts mannitol-induced hyponatremia, which develops in almost every patient treated by repeated doses of mannitol $[44,45]$.

Steroids are widely used to reduce oedema in brain tumours. However, they have not shown any benefit for brain oedema treatment in ischaemic stroke, although there are no trials investigating the use of steroids in space-occupying ischaemic 
stroke [46-49]. In addition, the rate of infections and complications in patients with diabetes mellitus is significantly increased with steroids.

\subsection{Intracranial pressure-lowering therapies}

Barbiturates have been administered in a variety of clinical conditions to control elevated ICP, especially in head trauma. Barbiturates may be helpful in acute ICP crisis in those patients awaiting more definitive treatment. Their routine use, however, is discouraged [27,28,50].

Buffer solutions may be used as an option when other interventions have failed. Tris-hydroxy-methyl-aminomethane (THAM) (Tris buffer) is given by continuous intravenous infusion via a central venous catheter $(1 \mathrm{mmol} / \mathrm{kg}$ as bolus infusion over 45 minutes followed by $0.25 \mathrm{mmol} / \mathrm{kg}$-hour, aiming for a target arterial $\mathrm{pH}$ of 7.5 to 7.55) [28]. THAM can be used to raise blood $\mathrm{pH}$ independently from respiratory function. The mode of action is probably related to neutralization of an acidosis-related vasodilatation and thus a decrease of ICP [28,51]. ICP should fall by 10 to $15 \mathrm{~mm} \mathrm{Hg}$ within 15 minutes after bolus infusion; otherwise, treatment is not effective $[27,28]$.

Hyperventilation is not recommended unless intracranial hypertension cannot be controlled by any other therapy and the patient is considered a candidate for more definitive treatment such as decompressive surgery $[27,28]$. The patient's respiratory mode is adjusted for $\mathrm{PaCO}_{2}$ (target 30 to $35 \mathrm{~mm} \mathrm{Hg}$ ) and venous oxygenation with jugular bulb oxymetry (>50\%), which is best achieved by raising the ventilation rate at a constant tidal volume. After $\mathrm{pCO}_{2}$ target is reached, it may take up to 30 minutes until ICP is reduced by $25 \%$ to $30 \%$. Prolonged hyperventilation is discouraged because the effect wears off within 3 to 4 hours $[27,28]$.

So far, none of these therapeutic strategies is supported by adequate evidence of efficacy from experimental studies or randomised clinical trials. To understand why medical treatment alone often fails to prevent clinical deterioration, the following points have to be remembered: (a) Clinical deterioration usually is not due to increases of global ICP but to massive local swelling and tissue shifts. Increase of ICP is a secondary late-stage result and represents a terminal and, most likely, an irreversible event that occurs when mass expansion exceeds intracranial compliance. (b) Many agents can work only at an intact blood-brain barrier, which is usually severely compromised in massive cerebral ischaemia. (c) CPP and midline shift are the major surrogate markers of treatment in massive infarction. ICP values are not associated with the extent of midline shift nor do they predict fatal outcomes, and reduction of ICP is not necessarily associated with an increase in CPP [52].

Therefore, from a pathophysiological point of view, all of the above-mentioned therapeutic strategies may be effective only for a short period of time, if at all, but are doomed to fail in the long term [44,53]. Several reports suggest that they are not only ineffective but even detrimental $[3,9,34,41,44,45,50$, 54-61]:

Osmotic therapy with hyperosmolar agents aimed at lowering ICP and reducing brain oedema by drawing water from infarcted tissue may be detrimental by primarily dehydrating intact brain, contracting healthy brain tissue volume, thereby aggravating pressure differentials, and causing devastating shifts of brain tissue $[6,42,44,58,62]$.

In malignant infarctions, there are large areas where the blood-brain barrier is significantly disrupted. Hyperosmolar agents have been demonstrated to accumulate in infarcted brain tissue, aggravating brain oedema and space occupation instead of reducing them and thereby (especially in the case of repeated use) worsening brain tissue shifts [55,59]. In addition, after discontinuing hyperosmolar therapy, rebound effects may occur [60,63-65].

Prolonged hyperventilation-induced hypocarbia and considerable decreases in cerebral blood flow by cerebral vasoconstriction both aggravate ischaemic brain injury [54,66-68]. Profound hyperventilation may also jeopardise oxygen delivery to the brain tissue at risk. The underlying physiological mechanism is the Bohr effect: In the presence of carbon dioxide, the dissociation of oxygen from haemoglobin increases. A decrease in blood carbon dioxide by hyperventilation increases the affinity of oxygen to haemoglobin. This leads to a reduction in brain tissue $\mathrm{pO} 2$ and, as a result, to increased ischaemic damage indicated by increases in extracellular glutamate, pyruvate, and lactate $[69,70]$.

In some patients with poor cerebral compliance, strict hyperventilation may cause paradoxical ICP elevation by increasing thoracic venous and cerebrospinal fluid pressure. Other side effects include barotrauma and hypokalemia. As with osmotherapy, adverse rebound effects may occur if normoventilation is resumed too rapidly $[26,28,54]$.

Barbiturates often do not lead to sustained control of ICP but may reduce CPP [50,71-75]. In addition, treatment may cause severe side effects such as hypotension, decreased cardiac performance, or severe infections. Cardiovascular side effects may be aggravated by concomitant dehydration advocated by osmotherapy and reduced cardiac filling pressures $[28,50]$.

As a result, none of the conservative treatment options has shown a beneficial effect on outcome in clinical trials, except for glycerol, for which a few clinical trials demonstrate an effect on short-time survival. However, glycerol also failed to demonstrate a long-term benefit $[46,61,76]$. This failure of conservative treatment is reflected by our clinical experience: In larger case series of maximum conservative treatment in 
Table 1

\begin{tabular}{|c|c|c|c|c|}
\hline Authors & Number & $\begin{array}{l}\text { Target } \\
\text { temperature }\end{array}$ & $\begin{array}{l}\text { Time to induction of } \\
\text { hypothermia (hours) }\end{array}$ & $\begin{array}{c}\text { Duration of } \\
\text { hypothermia (hours) }\end{array}$ \\
\hline Schwab et al., 1998 [95] & 25 & $33^{\circ} \mathrm{C}$ (external cooling) & $4-24$, mean $14 \pm 7$ & $48-72$ \\
\hline Schwab et al., 2001 [134] & 50 & $32^{\circ} \mathrm{C}-33^{\circ} \mathrm{C}$ (external cooling) & $4-75$, mean $22 \pm 9$ & $24-72$ \\
\hline Georgiadis et al., 2001 [99] & 6 & $33^{\circ} \mathrm{C}$ (endovascular cooling) & $12-58$, mean $28 \pm 17$ & $48-78$ \\
\hline Georgiadis et al., 2002 [124] & 19 & $\begin{array}{c}33^{\circ} \mathrm{C}(n=8 \text { endovascular cooling; } \\
n=11 \text { external cooling) }\end{array}$ & $18-24$, mean 24 & $24-116$ \\
\hline Milhaud et al., 2005 [94] & 12 & $32^{\circ} \mathrm{C}-33^{\circ} \mathrm{C}$ (external cooling) & $4-24$, mean $11 \pm 7$ & $120-504$ \\
\hline
\end{tabular}

Table 2

\begin{tabular}{|c|c|c|c|c|c|c|}
\hline Authors & Number & $\begin{array}{l}\text { Mean age } \\
\text { (years) }\end{array}$ & $\begin{array}{c}\text { Mortality in } \\
\text { hospital }\end{array}$ & $\begin{array}{l}\text { Mortality up } \\
\text { to } 3 \text { months }\end{array}$ & $\begin{array}{l}\text { Mortality up } \\
\text { to } 6 \text { months }\end{array}$ & $\begin{array}{l}\text { Mortality up } \\
\text { to } 12 \text { months }\end{array}$ \\
\hline Schwab et al., 1998 [95] & 25 & 49 & $44 \%$ & $48 \%$ & NA & NA \\
\hline Schwab et al., 2001 [134] & 50 & 57 & $38 \%$ & $38 \%$ & NA & NA \\
\hline Georgiadis et al., 2001 [99] a & 6 & 65 & $17 \%$ & NA & NA & NA \\
\hline Milhaud et al., 2005 [94] b & 10 & 52 & $50 \%$ & $50 \%$ & $50 \%$ & NA \\
\hline
\end{tabular}

aTarget temperature in one patient $34.5^{\circ} \mathrm{C}$. ${ }^{\mathrm{b}}$ Two patients were excluded in this analysis because they received hemicraniectomy in addition to hypothermia due to worsening of cerebral oedema on day 1 and day 7 , respectively; both survived. NA, not available.

malignant MCA infarction, case fatality rates are $53 \%$ to $78 \%$ $[3,11,77,78]$.

\section{Mild to moderate hypothermia}

Induced hypothermia is defined as physical or pharmacological lowering of the physiological body core temperature to $36.0^{\circ} \mathrm{C}$ to $36.5^{\circ} \mathrm{C}$ (minimal hypothermia), $33.0^{\circ} \mathrm{C}$ to $35.9^{\circ} \mathrm{C}$ (mild hypothermia), $28.0^{\circ} \mathrm{C}$ to $32.9^{\circ} \mathrm{C}$ (moderate hypothermia), or $10.0^{\circ} \mathrm{C}$ to $27.9^{\circ} \mathrm{C}$ (deep hypothermia) [79]. It is well known in ischaemic stroke that body temperature on admission and during the first 24 hours is associated with the extent of ischaemic damage and is an independent predictor of mortality and outcome [80-82].

Although the neuroprotective effect of hypothermia has been known since the 1950s, the earliest experimental findings in ischaemic stroke were reported in the late 1980s [83,84]. There are numerous animal experiments demonstrating promising results, but only a few of them on massive cerebral infarctions [85-88]. The beneficial effect was pronounced when hypothermia was started early and continued for more than 24 hours [89-91].

Only one randomised trial has investigated mild-moderate hypothermia in severe, but not necessarily malignant, stroke (cooling for acute ischaemic brain damage, or COOL-AID). Patients were randomly assigned to either hypothermia or standard medical treatment. Target temperature in the pilot trial was $32^{\circ} \mathrm{C}$ maintained for 12 to 72 hours. In the subsequent phase I trial, a target temperature of $33^{\circ} \mathrm{C}$ was maintained for 24 hours. Due to the small sample sizes, the studies did not show statistically significant differences in mortality or functional outcome [92,93]. There are no published controlled, randomised, or prospective comparative clinical studies of hypothermia in malignant MCA infarction. Available clinical studies in malignant cerebral infarction are listed in Table 1.

These report mortality rates of between $17 \%$ and $48 \%$ (Table 2). Data on functional outcome are summarized in Table 3. Only one study has evaluated functional outcome after 6 months in patients with malignant MCA infarction treated by hypothermia, and only 10 patients were involved [94]. Data on long-term outcome are completely lacking (Table 3).

Hypothermia in these studies was associated with a high rate of complications, the most frequent being pneumonia, severe bradycardia and heart failure with severe hypotension, and severe thrombocytopenia and coagulopathy. Especially in the rewarming phase, a high percentage of patients developed severe increases in ICP. Increased ICP and herniation were the most common reasons for early mortality [95]. Most studies on hypothermia in ischaemic stroke used body 


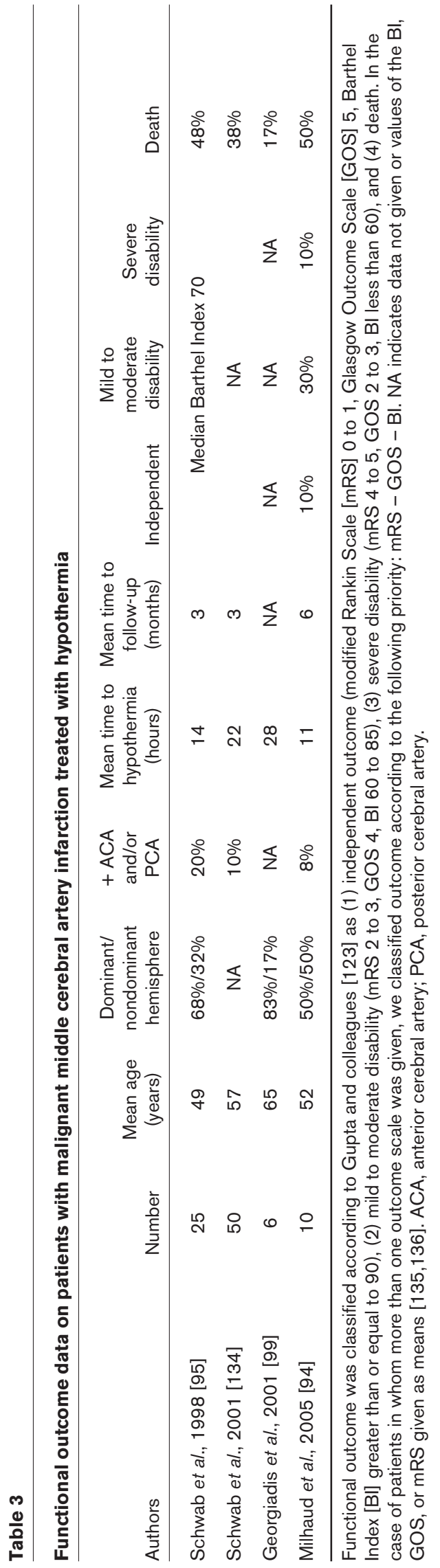

temperature for monitoring. It has to be kept in mind, however, that brain temperature is $0.5^{\circ} \mathrm{C} \pm 0.3^{\circ} \mathrm{C}$ above rectal temperature, that temperature within the brain may vary up to $1^{\circ} \mathrm{C}$, and that initial temperature in the ischaemic hemisphere is $0.8^{\circ} \mathrm{C}$ higher than in the healthy hemisphere [84,96-98].

As long as there is no sufficient evidence of benefit, hypothermia should be used only in the setting of clinical trials. Hypothermia is an invasive procedure that needs treatment in an experienced ICU, including ventilation, relaxation, and measurement of ICP. External cooling is complicated, especially in adipose patients because of the comparatively long time for cooling with increased use of muscle relaxants and anaesthetics. If available, endovascular cooling should be used because the target temperature can be obtained comparatively quickly (approximately 3.5 hours) [92,93,99]. Instead of passive rewarming, controlled rewarming and long rewarming periods $\left(+0.1^{\circ} \mathrm{C}\right.$ to $0.2^{\circ} \mathrm{C}$ per 2 to 4 hours) should be used to avoid increases in ICP or decreases in CPP [100]. Cooling of the head alone seems to be insufficient [96], although further clinical evaluation is required and devices are still being developed [101,102].

\section{Decompressive surgery}

Decompressive surgery in large ischaemic strokes dates back to as early as 1935 [103]. It is the only available treatment that primarily addresses mass effect, based on simple mechanical reasoning. The rationale is to remove a part of the neurocranium in order to create space to accommodate the swollen brain, to avoid ventricular compression, to reverse brain tissue shifts, and to prevent secondary mechanical tissue damage. Normalisation of ICP and tissue oxygenation is more a secondary effect [9,104-108].

Two different techniques are used: external decompression (removal of the cranial vault and duraplasty) or internal decompression (removal of nonviable, infarcted tissue [that is, in the case of malignant MCA infarction, temporal lobectomy]). The two can be combined [109,110]. In theory, resection of the temporal lobe may reduce the risk of uncal herniation. However, this has never been proven consistently by clinical studies, which show similar results as series using external decompression [111,112]. Resection of infarcted tissue is more complicated, and it is difficult to distinguish between already infarcted and potentially salvageable tissue. Therefore, in most institutions, external decompressive surgery (consisting of a large hemicraniectomy and duraplasty) is performed: In short, a large (reversed) question mark-shaped skin incision based at the ear is made. A bone flap with a diameter of at least $12 \mathrm{~cm}$ (including the frontal, parietal, temporal, and parts of the occipital squama) is removed. Additional temporal bone is removed so that the floor of the middle cerebral fossa can be explored. Then the dura is opened and an augmented dural patch, consisting of homologous periost and/or temporal fascia, is inserted 
Figure 1
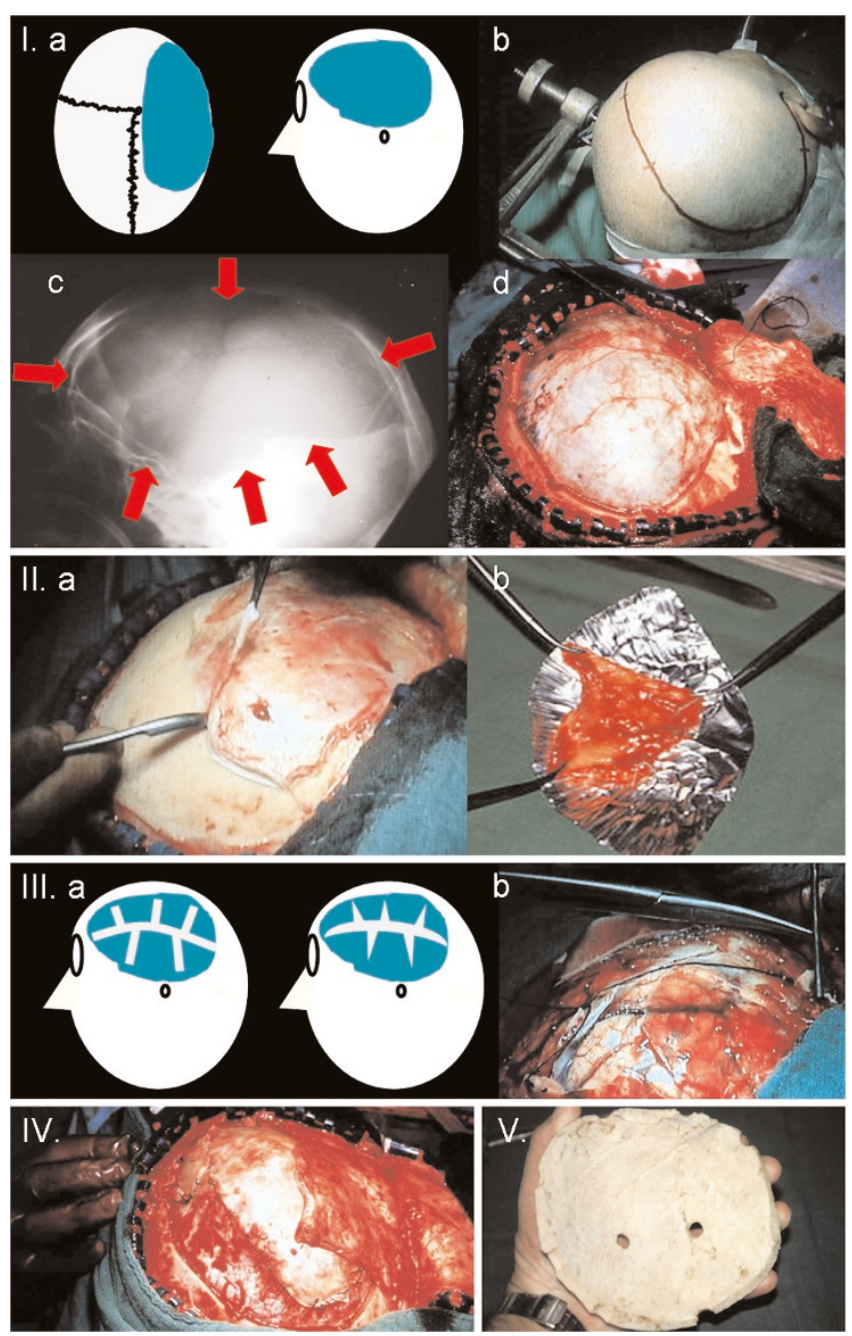

Hemicraniectomy: external decompressive surgery technique. I. Frontotemporo-parietal hemicraniectomy: (a) schematic drawing of the hemicraniectomy defect, (b) incision, (c) craniectomy borders (to the skull base), (d) tense dura mater with swollen brain underneath. II. Dura mater is removed for duraplasty: (a) preparation, (b) dura stretched on aluminium foil. III. Dura incisions: (a) schematic drawing of incisions, (b) preparation. IV. Insertion of the dura (duraplasty). V. Bone flap is stored at $-80^{\circ} \mathrm{C}$. Cranioplasty is performed after 6 to 12 weeks.

(usually, a patch of 15 to $20 \mathrm{~cm}$ in length and 2.5 to $3.5 \mathrm{~cm}$ in width is used). The dura is fixed at the margin of the craniotomy to prevent epidural bleeding. The temporal muscle and the skin flap are then reapproximated and secured. In surviving patients, cranioplasty usually is performed after 6 to 12 weeks, using the stored bone flap or an artificial bone flap (Figures 1 and 2). Complications occur rarely and include postoperative epidural and subdural haemorrhage and hygromas or wound and bone flap infections [77,109]. These can be recognized easily and usually do not contribute to perioperative mortality. A more common and far more serious problem is a hemicraniectomy
Figure 2

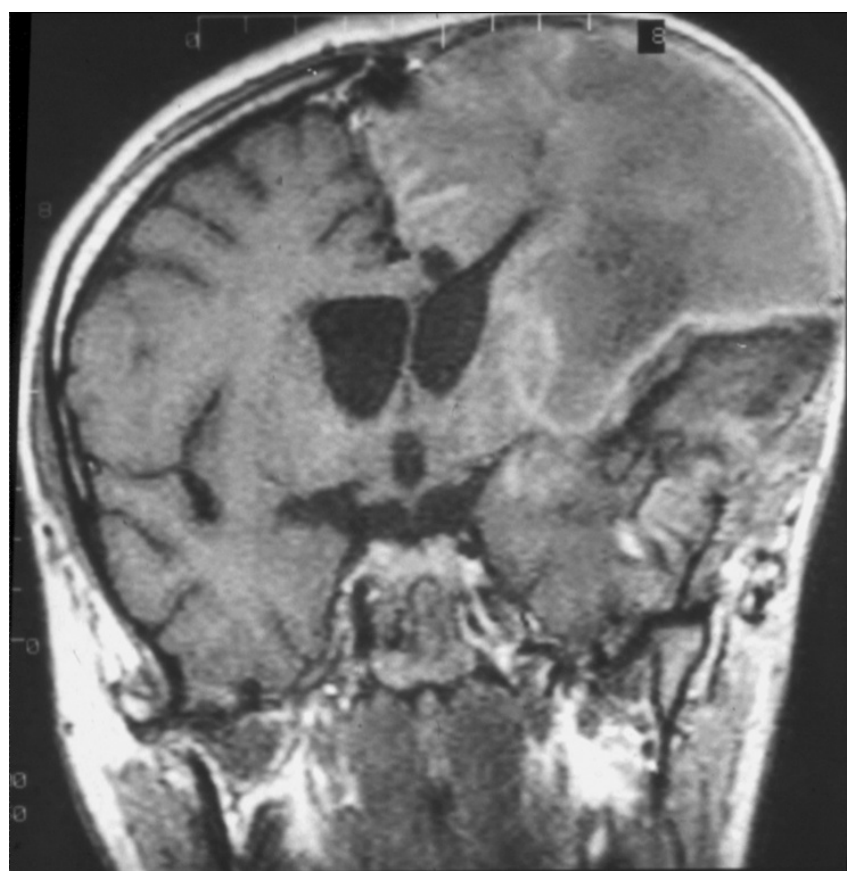

Left hemispheric malignant middle cerebral artery infarction after hemicraniectomy (magnetic resonance imaging). The swollen brain is allowed to expand outside.

that is too small. Because the proportion of brain tissue to be allowed to shift outside the skull is closely related to the diameter of the bone flap (which is removed), small hemicraniectomies not only are insufficient but may lead to herniation through the craniectomy defect [113]. Ventriculostomy is not recommended; although it may help to decrease ICP by allowing drainage of cerebrospinal fluid, it promotes brain tissue shifts at the same time and therefore may be detrimental.

Between 1935 and 2007, more than 80 case reports and series of patients with malignant brain infarctions including more than 1,700 patients have been published. Larger case series were not published until 1995 [77]. Only a few prospective trials have compared decompressive surgery with conservative treatment. Some of them used historical control groups, and most control groups consisted of patients with a higher age, more comorbidity, and (more frequently) lesions of the dominant hemisphere $[3,77,104,109,111,114-122]$. These studies report mortality rates of $0 \%$ to $33 \%$ in surgically treated patients compared with $60 \%$ to $100 \%$ in conservatively treated patients. In a review by Gupta and colleagues [123] analysing all available individual patient data from 138 patients, the overall mortality rate after hemicraniectomy after a period of 7 to 21 months was $24 \%$. Only one study compared decompressive surgery with hypothermia [124], and one study compared mild 
Mortality data in patients with malignant middle cerebral artery infarction: studies with comparative data on conservative treatment versus decompressive surgery

\begin{tabular}{|c|c|c|c|c|c|c|c|}
\hline Authors & $\begin{array}{l}\text { Patients } \\
\text { treated with } \\
\text { conservative } \\
\text { treatment }\end{array}$ & $\begin{array}{c}\text { Patients } \\
\text { treated with } \\
\text { decompressive } \\
\text { surgery }\end{array}$ & $\begin{array}{l}\text { Mean } \\
\text { age } \\
\text { (years) }\end{array}$ & $\begin{array}{l}\text { Mortality } \\
\text { in } \\
\text { hospital }\end{array}$ & $\begin{array}{c}\text { Mortality } \\
\text { up to } \\
3 \text { months }\end{array}$ & $\begin{array}{l}\text { Mortality } \\
\text { up to } \\
6 \text { months }\end{array}$ & $\begin{array}{l}\text { Mortality } \\
\text { up to } \\
12 \text { months }\end{array}$ \\
\hline Delashaw et al., $1990[118]^{a}$ & 4 & 9 & NA vs. 57 & $100 \%$ vs. $0 \%$ & $100 \%$ vs. $11 \%$ & $100 \%$ vs. NA & $100 \%$ vs. NA \\
\hline Steiger $1991[119]^{\mathrm{b}}$ & 7 & 8 & NA & $100 \%$ vs. $25 \%$ & $100 \%$ vs. $25 \%$ & $100 \%$ vs. $25 \%$ & NA \\
\hline $\begin{array}{l}\text { Rieke et al., } 1995 \text { [77], } \\
\text { Hacke et al., } 1996 \text { [3], } \\
\text { Wirtz et al., } 1997 \text { [104], } \\
\text { Schwab et al., } 1998 \text { [109]c }\end{array}$ & 55 & 63 & 56 vs. 50 & $78 \%$ vs. $25 \%$ & NA vs. $25 \%$ & NA & NA \\
\hline Holtkamp et al., $2001[114]^{\mathrm{d}}$ & 12 & 12 & 73 vs. 65 & $83 \%$ vs. $17 \%$ & $83 \%$ vs. $25 \%$ & $83 \%$ vs. $25 \%$ & $83 \%$ vs. $33 \%$ \\
\hline Mori et al., 2001 [120] & 15 & 19 & 72 vs. 63 & $60 \%$ vs. $11 \%$ & $67 \%$ vs. $16 \%$ & NA & NA \\
\hline Mori et al., 2004 [111] $^{\mathrm{e}}$ & 15 & 19 & 72 vs. 65 & $62 \%$ vs. $12 \%$ & NA & $71 \%$ vs. $24 \%$ & NA \\
\hline Kuroki et al., $2001[121]^{\dagger}$ & 7 & 8 & 80 vs. 72 & $86 \%$ vs. $13 \%$ & NA & NA & NA \\
\hline Cho et al., 2003 [115]g & 10 & 42 & 64 vs. 63 & $80 \%$ vs. $29 \%$ & NA & NA & NA \\
\hline Maramattom et al., $2004[116]^{\mathrm{h}}$ & 10 & 14 & 63 vs. 55 & $60 \%$ vs. $0 \%$ & NA & NA & NA \\
\hline Yang et al., 2005 [122] & 14 & 10 & 66 vs. 59 & $64 \%$ vs. $10 \%$ & $64 \%$ vs. $10 \%$ & NA & NA \\
\hline Wang et al., 2006 [117] & 41 & 21 & 67 vs. 62 & NA & NA & $22 \%$ vs. $29 \%$ & NA \\
\hline Authors & $\begin{array}{l}\text { Patients } \\
\text { treated with } \\
\text { hypothermia }\end{array}$ & $\begin{array}{c}\text { Patients } \\
\text { treated with } \\
\text { decompressive } \\
\text { surgery }\end{array}$ & $\begin{array}{l}\text { Mean } \\
\text { age } \\
\text { (years) }\end{array}$ & $\begin{array}{l}\text { Mortality } \\
\text { in } \\
\text { hospital }\end{array}$ & $\begin{array}{l}\text { Mortality } \\
\text { up to } \\
3 \text { months }\end{array}$ & $\begin{array}{l}\text { Mortality } \\
\text { up to } \\
6 \text { months }\end{array}$ & $\begin{array}{l}\text { Mortality } \\
\text { up to } \\
12 \text { months }\end{array}$ \\
\hline Georgiadis et al., 2002 [124] & 19 & 17 & 56 vs. 52 & $47 \%$ vs. $12 \%$ & NA & NA & NA \\
\hline Authors & $\begin{array}{c}\text { Patients } \\
\text { treated with } \\
\text { decompressive } \\
\text { surgery }+ \\
\text { hypothermia }\end{array}$ & $\begin{array}{c}\text { Patients } \\
\text { treated with } \\
\text { decompressive } \\
\text { surgery }\end{array}$ & $\begin{array}{l}\text { Mean } \\
\text { age } \\
\text { (years) }\end{array}$ & $\begin{array}{l}\text { Mortality } \\
\text { in } \\
\text { hospital }\end{array}$ & $\begin{array}{l}\text { Mortality } \\
\text { up to } \\
3 \text { months }\end{array}$ & $\begin{array}{l}\text { Mortality } \\
\text { up to } \\
6 \text { months }\end{array}$ & $\begin{array}{l}\text { Mortality } \\
\text { up to } \\
12 \text { months }\end{array}$ \\
\hline Els et al., 2006 [125]k & 12 & 13 & 49 vs. 49 & $8 \%$ vs. $15 \%$ & $8 \%$ vs. $15 \%$ & $8 \%$ vs. $15 \%$ & NA \\
\hline
\end{tabular}

aNot randomised. All four patients in the nonintervention group had a dominant MCA infarction, and all nine patients in the intervention group had a nondominant MCA infarction.

bNot randomised. All patients were younger than 60 years. There is a selection bias because conservatively treated patients were not regarded as being suitable for surgery.

cNot randomised. These studies represent the largest case series in the literature using the case series of Hacke and colleagues (1996) [3] as historical control group. Mortality rates of early versus delayed surgery were $16 \%$ versus $34 \%$.

dNot randomised. There is a selection bias by advanced age and more comorbidity in conservatively treated patients. All patients were older than 55 and younger than 75 years.

eNot randomised. There is a selection bias because treatment decision was based primarily on the consent by the patient's relatives. Some patients received internal decompression.

Mortality rates of early versus late surgery were $19 \%$ versus $28 \%$. The case series of 2004 included the patients of the case series of 2001 .

fNot randomised. The study used historical controls.

gNot randomised. Mortality rates of ultra-early ( $<6$ hours) versus delayed surgery were $8 \%$ versus $37 \%$.

hNot randomised. Hemicraniectomy was performed only in patients, who deteriorated clinically.

iNot randomised.

jNot randomised. There was no difference between late and early hemicraniectomies.

kRandomised. Twelve patients received mild hypothermia $\left(35^{\circ} \mathrm{C}\right)$ in addition to hemicraniectomy. In the group treated by hemicraniectomy alone more patients had a right-sided infarction and additional infarction of the ACA or PCA.

$\mathrm{ACA}$, anterior cerebral artery; NA, not available; PCA, posterior cerebral artery.

hypothermia plus hemicraniectomy with hemicraniectomy alone [125] (Tables 4 and 5).
Various trials suggest that decompressive surgery not only reduces mortality but also increases the number of patients 
Table 5

Mortality data in patients with malignant middle cerebral artery infarction: studies with reviews on conservative treatment versus decompressive surgery

\begin{tabular}{lcccc}
\hline Authors & $\begin{array}{c}\text { Patients treated with } \\
\text { conservative treatment }\end{array}$ & $\begin{array}{c}\text { Patients treated with } \\
\text { decompressive surgery }\end{array}$ & Mean age (years) & Mortality \\
\hline Gupta et al., 2004 [123] & - & 138 & 50 & $\begin{array}{c}\text { Overall mortality 24\% } \\
\text { (follow-up 7-21 months) }\end{array}$ \\
Morley et al., 2002 [137] & No trial fulfills the criteria of a randomised controlled study design to be included in a meta-analysis. \\
\hline
\end{tabular}

with independent functional outcome without increasing the number of severely disabled patients [109,111,115,118, 126]. Other studies doubt these results, especially in patients with increased age and with additional infarction of the ACA or PCA [116,117,122,127,128]. Among other predictors that have been proposed to predict unfavourable outcome are preoperative midline shift, low preoperative GCS, presence of anisocoria, early clinical deterioration, and internal carotid artery occlusion $[129,130]$. In the review by Gupta and colleagues [123], age was the only prognostic factor for poor outcome, whereas time to surgery, the presence of brainstem signs prior to surgery, and additional infarction of the ACA or PCA territory were not associated with outcome. Data from comparative studies and reviews are summarized in Tables 6 and 7.

These controversial results lead to constant discussion among experts about the benefit of decompressive surgery in malignant MCA infarction and to large regional differences in the application of the procedure. This dilemma could be resolved only by randomised trials. Since 2000, five randomised trials have been conducted: the American HeADDFIRST (Hemicraniecomy And Durotomy Upon Deterioration From Infarction Related Swelling Trial), the French DECIMAL (DEcompressive Craniectomy In MALignant middle cerebral artery infarcts) trial, the Dutch HAMLET (Hemicraniectomy After Middle cerebral artery infarction with Life-threatening Edema Trial), the Philippine HeMMI (Hemicraniectomy For Malignant Middle Cerebral Artery Infarcts) trial, and the German DESTINY (DEcompressive Surgery for the Treatment of malignant INfarction of the middle cerebral arterY) trial [16-18,131,132].

DESTINY and DECIMAL were stopped early in 2006, and the results were published recently $[16,17]$. In both trials, decompressive surgery significantly reduced mortality, but the primary endpoint in both trials, dichotomization of the modified Rankin scale (mRS) score of less than or equal to 3, failed to show statistically significant results. Nevertheless, both trials were stopped not only because of ethical considerations to continue randomisation, but also because of expectations of a prospectively planned pooled analysis of the three European trials (DECIMAL, DESTINY, and
HAMLET). This pooled analysis is the first in the field of stroke in which individual patient data from three different randomised trials were pooled while these trials were still ongoing. Of the 93 patients who were included, 51 were randomly assigned to decompressive surgery and 42 to conservative treatment. Results demonstrate that decompressive surgery (a) significantly reduces mortality (71\% versus $22 \%, p<0.0001$, absolute risk reduction [ARR] $50 \%$ ), (b) significantly increases the chance to survive with an $\mathrm{mRS}$ score of less than or equal to 4 (that is, not being bedridden and completely dependent) (24\% versus $75 \%$, $p<0.0001$, ARR 51\%), and (c) also significantly increases the chance to survive with an $\mathrm{mRS}$ score of less than or equal to 3 (that is, being able to walk and being independent in at least some activities of daily living) (21\% versus $43 \%$, $p<0.014$, ARR 23\%) (Figures 3 and 4) [133]. There is no statistically significant heterogeneity between the three trials, and the treatment effects remain essentially the same for all analyses if baseline differences between the treatment groups are taken into account. The resulting numbers needed to treat are 2 for survival, 2 for the prevention of an $m R S$ score of 5 or death, and 4 for the prevention of an $\mathrm{mRS}$ score of 4 or 5 or death. Decompressive surgery was beneficial in all predefined subgroups, including age (dichotomized at 50 years), presence of aphasia, and time to randomisation (dichotomized at 21.5 hours), as measured by an mRS score of less than or equal to 4 at 12 months.

\section{Summary}

For many years, there has been no agreement among experts concerning the question of which treatment is beneficial in patients with malignant MCA infarctions. In comparison with the usually unsuccessful conservative treatment strategies, hypothermia and decompressive surgery seem to be much more promising therapies $[9,53,95]$. Although hypothermia has been demonstrated to be feasible in patients with large hemispheric infarctions, data on safety and efficacy are currently insufficient to recommend hypothermia in patients with malignant infarctions outside clinical trials [99,134].

Because of promising results from numerous case reports, retrospective case series, and a small number of prospective studies, decompressive surgery has already been increasingly 


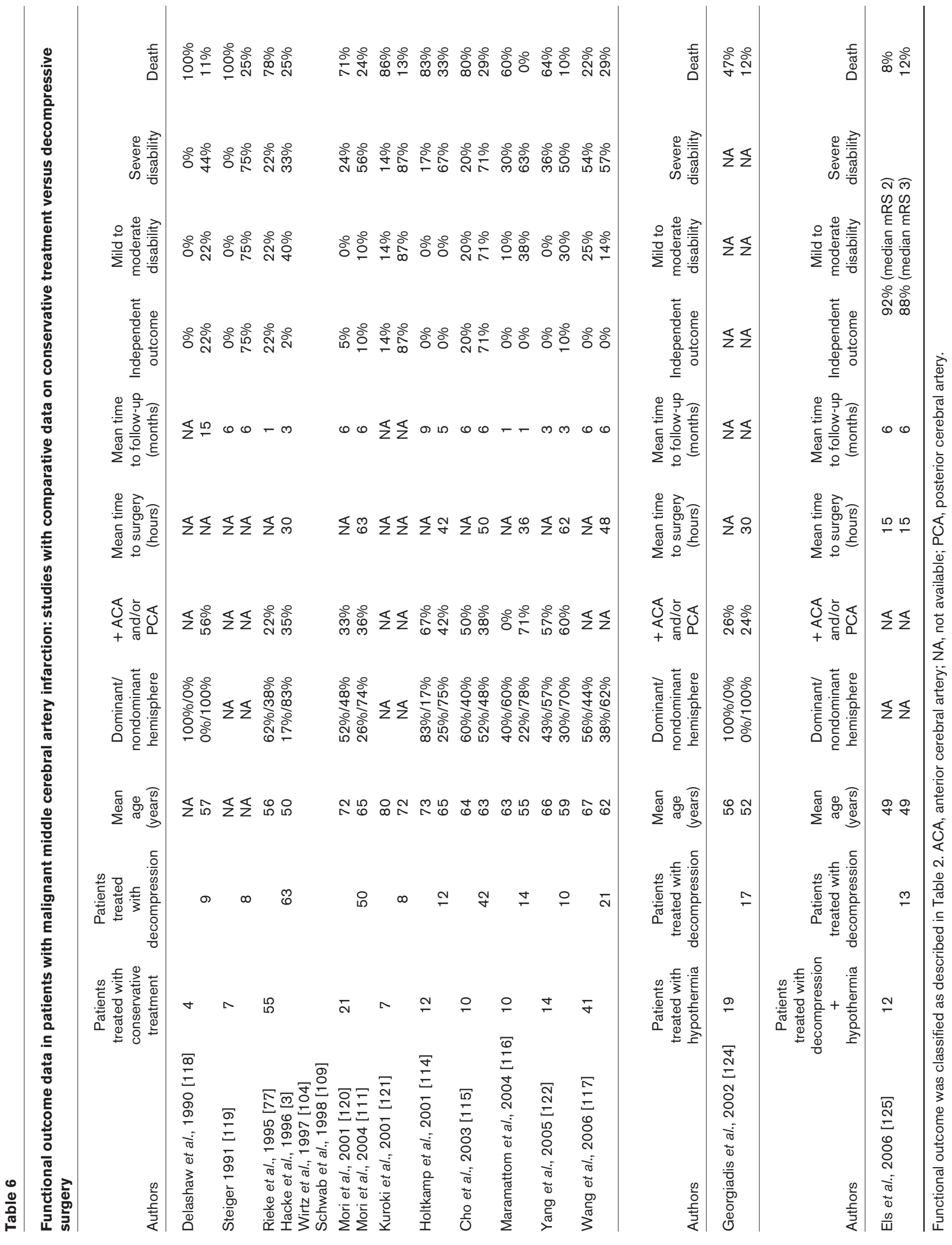




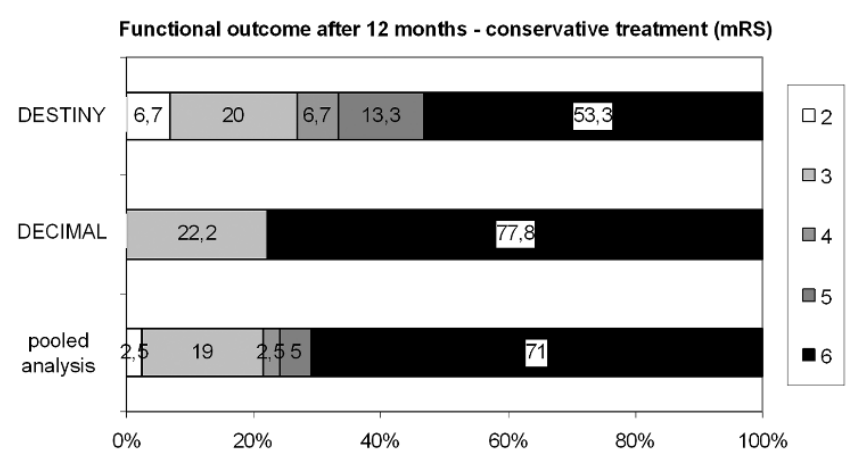

Mortality and functional outcome after conservative treatment in patients with malignant middle cerebral artery infarction. Results from randomised controlled trials. The pooled analysis includes 93 patients (all patients from DECIMAL and DESTINY and 23 patients from HAMLET). DECIMAL, DEcompressive Craniectomy In MALignant middle cerebral artery infarcts; DESTINY, DEcompressive Surgery for the Treatment of malignant INfarction of the middle cerebral arterY; HAMLET, Hemicraniectomy After Middle cerebral artery infarction with Life-threatening Edema Trial; mRS, modified Rankin scale.

Figure 4

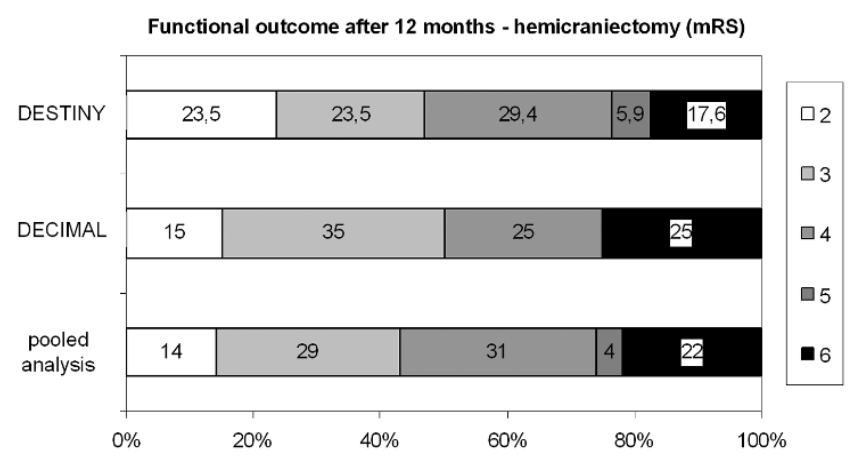

Mortality and functional outcome after hemicraniectomy in patients with malignant middle cerebral artery infarction. Results from randomised controlled trials. The pooled analysis includes 93 patients (all patients from DECIMAL and DESTINY and 23 patients from HAMLET).

DECIMAL, DEcompressive Craniectomy In MALignant middle cerebral artery infarcts; DESTINY, DEcompressive Surgery for the Treatment of malignant INfarction of the middle cerebral arterY; HAMLET,

Hemicraniectomy After Middle cerebral artery infarction with Lifethreatening Edema Trial; mRS, modified Rankin scale.

incorporated into routine intensive care protocols $[77,109$, 123]. In 2007, the results from nonrandomised studies were confirmed by a pooled analysis of three randomised controlled trials, supporting the widespread opinion among experts that hemicraniectomy in malignant MCA infarction not only reduces mortality but also leads to an improved outcome of the survivors without increasing the number of completely dependent patients [133]. So far, early hemicraniectomy is the only effective treatment in malignant ischaemic stroke. 
This article is part of a review series on Stroke, edited by David Menon.

Other articles in the series can be found online at http://ccforum.com/articles/

theme-series.asp?series=CC_Stroke

\section{Competing interests}

The authors declare that they have no competing interests.

\section{References}

1. Silver SL, Norris JW, Lewis AJ, Hachinski VC: Early mortality following stroke: a prospective review. Stroke 1984, 15:492-496.

2. Ropper $\mathrm{AH}$, Shafran B: Brain edema after stroke. Clinical syndrome and intracranial pressure. Arch Neurol 1984, 41:26-29.

3. Hacke W, Schwab S, Horn M, Spranger M, DeGeorgia M, von Kummer R: 'Malignant' middle cerebral artery infarction. Clinical course and prognostic signs. Arch Neurol 1996, 53:309315.

4. Shaw CM, Alvord EC Jr, Berry RG: Swelling of the brain following ischemic infarction with arterial occlusion. Arch Neurol 1959, 1:161-177.

5. $\mathrm{Ng}$ LK, Nimmannitya J: Massive cerebral infarction with severe brain swelling: a clinicopathological study. Stroke 1970, 1:158163.

6. Frank J: Large hemispheric infarction, deterioration, and intracranial pressure. Neurology 1995, 45:1 286-1290.

7. Sakai K, Iwahashi K, Terada K, Gohda Y, Sakurai M, Matsumoto Y. Outcome after external decompression for massive cerebral infarction. Neurol Med Chir 1998, 38:131-135.

8. Heinsius T, Bogousslavsky J, Van Melle G: Large infarcts in the middle cerebral artery territory. Etiology and outcome patterns. Neurology 1998, 59:341-350.

9. Schwab S, Rieke K, Aschoff A, Albert F, von Kummer R, Hacke W: Hemicraniectomy in space-occupying hemispheric infarction: useful early intervention or desperate activism? Cerebrovasc Dis 1996, 6:325-329.

10. Wijdicks EF, Diringer MN: Middle cerebral artery territory infarction and early brain swelling: progression and effect of age on outcome. Mayo Clin Proc 1998, 73:829-836.

11. Berrouschot J, Sterker M, Bettin S, Koster J, Schneider D: Mortality of space-occupying (malignant) middle cerebral artery infarction under conservative intensive care. Intensive Care Med 1998, 24:620-623.

12. Krieger DW, Demchuk AM, Kasner SE, Kauss M, Hantson L: Early clinical and radiological predictors of fatal brain swelling in ischemic stroke. Stroke 1999, 30:287-292.

13. Brott T, Adams HP, Olinger CP, Marler JR, Barsan WG, Biller J, Spilker J, Holleran R, Hertzberg V, Rorick M, et al.: Measurements of acute cerebral infarction: a clinical examination scale. Stroke 1989, 20:864-870.

14. Barber PA, Demchuk AM, Zhang J, Kasner SE, Hill MD, Berrouschot J, Schmutzhard E, Harms L, Verro P, Krieger D: Computed tomographic parameters predicting fatal outcome in large middle cerebral artery infarction. Cerebrovasc Dis 2003, 16:230-235.

15. Oppenheim $C$, Samson $Y$, Manaï $R$, Lalam $T$, Vandamme $X$, Crozier S, Srour A, Cornu P, Dormont D, Rancurel G, et al.: Prediction of malignant middle cerebral artery infarction by diffusion-weighted imaging. Stroke 2000, 31:2175-2181.

16. Vahedi K, Vicaut E, Mateo J, Kurtz A, Orabi M, Guichard JP, Boutron C, Couvreur G, Rouanet F, Touze E, et al:: Sequentialdesign, multicenter, randomized, controlled trial of early decompressive craniectomy in malignant middle cerebral artery infarction (DECIMAL Trial). Stroke 2007, 38:2506-2517.

17. Juttler E, Schwab S, Schmiedek P, Unterberg A, Hennerici M, Woitzik J, Witte S, Jenetzky E, Hacke W: Decompressive Surgery for the Treatment of Malignant Infarction of the Middle Cerebral Artery (DESTINY): a randomized, controlled trial. Stroke 2007, 38:2518-2525.
18. Hofmeijer J, Amelink GJ, Algra A, van Gijn J, Macleod MR, Kappelle LJ, van der Worp HB; the HAMLET investigators: Hemicraniectomy after middle cerebral artery infarction with life-threatening edema trial (HAMLET). Protocol for a randomised controlled trial of decompressive surgery in spaceoccupying hemispheric infarction. Trials 2006, 7:29.

19. Adams HP, Brott TG, Crowell RM, Furlan AJ, Gomez CR, Grotta J, Helgason CM, Marler JR, Woolson RF, Zivin JA, et al:: Guidelines for the management of patients with acute ischemic stroke: A statement for healthcare professionals from a special writing group of the Stroke Council, American Heart Association. Stroke 1994, 25:1901-1914.

20. Adams H, Adams RJ, DelZoppo G, Goldstein LB. Guidelines for the early management of patients with ischemic stroke: 2005 guidelines update a scientific statement from the Stroke Council of the American Heart Association/American Stroke Association. Stroke 2005, 36:916-923.

21. The European Stroke Initiative Executive Committee and the EUSI Writing Committee: European Stroke Initiative Recommendations for Stroke Management - Update 2003. Cerebrovasc Dis 2003, 16:311-337.

22. Chalela JA, Dunn B, Todd JW, Warach S: Induced hypertension improves cerebral blood flow in acute ischemic stroke. Neurology 2005, 64:1979.

23. Ahmed N, Wahlgren G: High initial blood pressure after acute stroke is associated with poor functional outcome. J Intern Med 2001, 249:467-473.

24. Britton M, Roeden A: Progression of stroke after arrival at hospital. Stroke 1985, 16:629-632.

25. Schwarz S, Georgiadis D, Aschoff A, Schwab S: Effects of induced hypertension on intracranial pressure flow velocities of the middle cerebral arteries in patients with large hemispheric stroke. Stroke 2002, 33:998-1004.

26. Hacke W, Steiner T, Schwab S: Critical care of stroke. In Cerebrovascular Disorders. Edited by Batjer HH, Caplan LR. London, UK: Butterworth; 1997:523-534.

27. Demchuk AM, Krieger DW: Mass effect with cerebral infarction. Curr Treat Options Neurol 1999, 1:189-199.

28. Steiner $T$, Ringleb $P$, Hacke $W$ : Treatment options for large hemispheric stroke. Neurology 2001, 57 Suppl:61-68.

29. Drakulovic MB, Torres A, Bauer TT, Nicolas JM, Nogue S, Ferrer M: Supine body position as a risk factor for nosocomial pneumonia in mechanically ventilated patients: a randomised trial. Lancet 1999, 354:1851-1858.

30. Schulz-Stubner S, Thiex R: Raising the head-of-bed by $\mathbf{3 0}$ degrees reduces ICP and improves CPP without compromising cardiac output in euvolemic patients with traumatic brain injury and subarachnoid haemorrhage: a practice audit. Eur J Anaesthesio/ 2006, 23:177-180.

31. Meixensberger J, Baunach S, Amschler J, Dings J, Rossen K: Influence of body position on tissue- $\mathrm{pO}_{2}$, cerebral perfusion pressure and intracranial pressure in patients with acute brain injury. Neurol Res 1997, 19:249-253.

32. $\mathrm{Ng} \mathrm{l}$, Lim J, Wong HB: Effects of head posture on cerebral hemodynamics: its influences on intracranial pressure, cerebral perfusion pressure, and cerebral oxygenation. Neurosurgery 2004, 54:593-597.

33. Rosner MJ, Coley IB: Cerebral perfusion pressure, intracranial pressure, and head elevation. J Neurosurg 1986, 65:636-641

34. Schwarz S, Georgiadis D, Aschoff A, Schwab S: Effects of body position on intracranial pressure and cerebral perfusion in patients with large hemispheric stroke. Stroke 2002, 33:497-501.

35. Feldman Z, Kanter MJ, Robertson CS, Contant CF, Hayes C, Sheinberg MA, Villareal CA, Narayan RK, Grossman RG: Effects of head elevation on intracranial pressure, cerebral perfusion pressure, and cerebral blood flow in head-injured patients. $J$ Neurosurg 1992, 76:207-211.

36. Schneider GH, von Helden GH, Franke R, Lanksch WR, Unterberg A: Influence of body position on jugular venous oxygen saturation, intracranial pressure, and cerebral perfusion pressure. Acta Neurochir Suppl (Wien) 1993, 59:107-112.

37. Moraine JJ, Berre J, Melot C: Is cerebral perfusion pressure a major determinant of cerebral blood flow during head elevation in comatose patients with severe intracranial lesions? $J$ Neurosurg 2000, 92:606-614.

38. Steiner T, Mendoza G, De Georgia M, Schellinger P, Holle R, Hacke W: Prognosis of stroke patients requiring mechanical 
ventilation in a neurological critical care unit. Stroke 1997, 28: 711-715.

39. Georgiadis D, Schwarz S, Kollmar R, Baumgartner RW, Schwab $S$ : Influence of inspiration:expiration ratio on intracranial and cerebral perfusion pressure in acute stroke patients. Intensive Care Med 2002, 28:1089-1093.

40. Georgiadis D, Schwarz S, Baumgartner RW, Veltkamp R, Schwab S: Influence of positive end-expiratory pressure on intracranial pressure and cerebral perfusion pressure in patients with acute stroke. Stroke 2001, 32:2088-2092.

41. Hofmeijer J, van der Worp HB, Kappelle LJ: Treatment of spaceoccupying cerebral infarction. Crit Care Med 2003, 31:617625.

42. Manno EM, Adams RE, Derdeyn CP, Powers WJ, Diringer MN: The effects of mannitol on cerebral edema after large hemispheric cerebral infarct. Neurology 1999, 52:583-587.

43. Zornow MH: Hypertonic saline as a safe and efficacious treatment of intracranial hypertension. J Neurosurg Anesthesiol 1996, 8:175-177.

44. Schwarz S, Schwab S, Bertram M, Aschoff A, Hacke W: Effects of hypertonic saline, hydroxyethyl starch solution, and mannitol in patients with increased intracranial pressure after stroke. Stroke 1998, 29:1550-1555.

45. Schwarz S, Georgiadis D, Aschoff A, Schwab S: Effects of hypertonic $(10 \%)$ saline in patients with raised intracranial pressure after stroke. Stroke 2002, 33:136-140.

46. Candelise L, Colombo A, Spinnler H: Therapy against brain swelling in stroke patients. A retrospective clinical study on 227 patients. Stroke 1975, 6:353-356.

47. Norris JW, Hachinski VC: High dose steroid treatment in cerebral infarction. Br Med J 1986, 292:21-23.

48. de Courten-Myers GM, Kleinholz M, Wagner KR, Xi G, Myers RE: Efficacious experimental stroke treatment with high-dose methylprednisolone. Stroke 1994, 25:487-493.

49. Qizilbash N, Lewington SL, Lopez-Arrieta JM: Corticosteroids for acute ischaemic stroke. Cochrane Database Syst Rev 2000: CD000064.

50. Schwab S, Spranger M, Schwarz S, Hacke W: Barbiturate coma in severe hemispheric stroke: useful or obsolete? Neurology 1997, 48:1608-1613.

51. Bouma GJ, Muizelaar JP: Cerebral blood flow, cerebral blood volume, and cerebrovascluar reactivity after severe head injury. J Neurotrauma 1992, 1 Suppl:333-348.

52. Schwab S, Aschoff A, Spranger M, Albert F, Hacke W: The value of intracranial pressure monitoring in acute hemispheric stroke. Neurology 1996, 47:393-398.

53. Schwab S, Hacke W: Surgical decompression of patients with large middle cerebral artery infarcts is effective. Stroke 2003, 34:2304-2305

54. Muizelaar JP, Marmarou A, Ward JD, Kontos HA, Choi SC, Becker DP, Gruemer H, Young HF: Adverse effects of prolonged hyperventilation in patients with severe head injury: a randomized clinical trial. J Neurosurg 1991, 75:731-739.

55. Kaufmann AM, Cardoso ER: Aggravation of vasogenic cerebral edema by multiple-dose mannitol. J Neurosurg 1992, 77:584589.

56. Van der Worp HB, Kappelle LJ: Complications of acute ischaemic stroke. Cerebrovasc Dis 1998, 8:124-132.

57. Wijdicks EFM: Management of massive hemispheric cerebral infarct: is there a ray of hope? Mayo Clin Proc 2000, 75:945952

58. Videen TO, Zazulia AR, Manno EM, Derdeyen CP, Adams RE, Diringer MN, Powers WJ: Mannitol bolus preferentially shrinks non-infarcted brain in patients with ischemic stroke. Neuro/ogy 2001, 57:2120-2122.

59. Bahrdwaj A, Harukuni I, Murphy SJ, Alakayed, NJ, Crain BJ, Koehler RC, Hurn PD, Traystman RJ: Hypertonic saline worsens infarct volume after transient focal ischemia in rats. Stroke 2000, 31:1694-1701.

60. Bereczki D, Liu M, do Prado GF, Fekete I: Mannitol for acute stroke. Cochrane Database Syst Rev 2001:CD001153.

61. Righetti E, Celani MG, Cantisani T, Sterzi R, Boysen G, Ricci S: Glycerol for acute stroke. Cochrane Database Syst Rev 2000:CD000096.

62. Paczynski RP, He YY, Diringer MN, Hsu CY: Multiple-dose mannitol reduces brain water content in a rat model of cortical infarction. Stroke 1997, 28:1437-1443.
63. Kotwica Z, Persson L: Effect of mannitol on intracranial pressure in focal cerebral ischemia: an experimental study in rats. Mater Med Pol 1991, 23:280-284.

64. Nau R, Prins FJ, Kolenda H, Prange HW: Temporary reversal of serum to cerebrospinal fluid glycerol concentration gradient after intravenous infusion of glycerol. Eur J Clin Pharmacol 1992, 42:181-185.

65. Nau R, Desel H, Lassek C, Thiel A, Schinschke S, Rossing R, Kolenda $\mathrm{H}$, Pranke HW: Slow elimination of mannitol from human cerebrospinal fluid. Eur J Clin Pharmacol 1997, 53:271274.

66. Muizelaar JP, van der Poel HG, Li ZC, Kontos HA, Levasseur JE: Pial arteriolar vessel diameter and $\mathrm{CO}_{2}$ reactivity during prolonged hyperventilation in the rabbit. J Neurosurg 1988, 69: 923-927.

67. Yundt KD, Diringer MN: The use of hyperventilation and its impact on cerebral ischemia in the treatment of traumatic brain injury. Crit Care Clin 1997, 13:163-184.

68. Stringer WA, Hasso AN, Thompson JR, Hinshaw DB, Jordan KG: Hyperventilation-induced cerebral ischemia in patients with acute brain lesions: demonstration by xenon-enhanced CT. AJNR Am J Neuroradiol 1993, 14:475-484.

69. Carmona Suazo JA, Maas Al, van den Brink WA, van Santbrink H, Steyerberg $\mathrm{EW}$, Avezaat $\mathrm{CJ}$ : $\mathrm{CO}_{2}$ reactivity and brain oxygen pressure monitoring in severe head injury. Crit Care Med, 2000, 28:3268-3274.

70. Marion DW, Puccio A, Wisniewski SR, Kochanek P, Dixon CE, Bullian L, Carlier P: Effect of hyperventilation on extracellular concentrations of glutamate, lactate, pyruvate, and local cerebral blood flow in patients with severe traumatic brain injury. Crit Care Med, 2002, 30:2619-2625.

71. Hoff JT, Nishimura M, Newfield P: Pentobarbital protection from cerebral infarction without suppression of edema. Stroke 1982, 13:623-628.

72. Pappas TN, Mironovich RO: Barbiturate-induced coma to protect against cerebral ischemia and increased intracranial pressure. Am J Hosp Pharm 1981, 38:494-498.

73. Shapiro HM: Barbiturates in brain ischaemia. $\mathrm{Br} J$ Anaesth $1985, \mathbf{5 7}: 82-95$

74. Woodcock J, Ropper AH, Kennedy SK: High dose barbiturates in non-traumatic brain swelling: ICP reduction and effect on outcome. Stroke 1982, 13:785-787.

75. Rockoff MA, Marshall LF, Shapiro HM: High-dose barbiturate therapy in humans: a clinical review of 60 patients. Ann Neurol 1979, 6:194-199.

76. Santambrogio S, Martinotti R, Sardella F, Porro F, Randazzo A: Is there a real treatment for stroke? Clinical and statistical comparison of different treatments in 300 patients. Stroke 1978, 9: 130-132.

77. Rieke K, Schwab S, Krieger D, von Kummer R, Aschoff A, Schuchardt V, Hacke W: Decompressive surgery in spaceoccupying hemispheric infarction: Results of an open, prospective trial. Crit Care Med 1995, 23:1576-1587.

78. Kasner SE, Demchuk AM, Berrouschot J, Schmutzhard E, Harms L, Verro P, Chalela JA, Abbur R, McGrade H, Christou I, et al.: Predictors of fatal brain edema in massive hemispheric ischemic stroke. Stroke 2001, 32:2117-2123.

79. Bernard SA, Buist M: Induced hypothermia in critical care medicine: a review. Crit Care Med 2003, 31:2041-2051.

80. Castillo J, Davalos A, Marrugat J, Noya M: Timing for feverrelated brain damage in acute ischemic stroke. Stroke 1998 , 29:2455-2460.

81. Wang Y, Lim LL, Levi C, Heller RF, Fisher J: Influence of admission body temperature on stroke mortality. Stroke 2000, 31: 404-409.

82. Reith J, Jorgensen HS, Pedersen PM, Nakayama $H$, Raaschou $\mathrm{HO}$, Jeppesen LL, Olsen TS: Body temperature in acute stroke: relation to stroke severity, infarct size, mortality, and outcome. Lancet 1996, 347:422-425.

83. Busto R, Dietrich WD, Globus MY, Valdes I, Scheinberg P, Ginsberg MD: Small differences in intraischemic brain temperature critically determine the extent of ischemic neuronal injury. $J$ Cereb Blood Flow Metab 1987, 7:729-738.

84. Busto R, Dietrich WD, Globus MYT, Ginsberg MD: The importance of brain temperature in cerebral ischemic injury. Stroke 1989, 20:1113-1114.

85. Morikawa E, Ginsberg MD, Dietrich WD, Duncan RC, Kraydieh S, 
Globus MY, Busto R: The significance of brain temperature in focal cerebral ischemia: histopathological consequences of middle cerebral artery occlusion in the rat. J Cereb Blood Flow Metab 1992, 12:380-389.

86. Yanamoto H, Nagata I, Niitsu Y, Zhang Z, Xue JH, Sakai N, Kikuchi $\mathrm{H}$ : Prolonged mild hypothermia therapy protects the brain against permanent focal ischemia. Stroke 2001, 32:232239.

87. Colbourne F, Corbett D, Zhao Z, Yang J, Buchan AM: Prolonged but delayed postischemic hypothermia: a long-term outcome study in the rat middle cerebral artery occlusion model. J Cereb Blood Flow Metab 2000, 20:1702-1708.

88. Kollmar R, Schabitz WR, Heiland S, Georgiadis D, Schellinger PD, Bardutzky J, Schwab S: Neuroprotective effect of delayed moderate hypothermia after focal cerebral ischemis: an MRI study. Stroke 2002, 33:1899-1904.

89. Corbett $D$, Thornhill J: Temperature modulation (hypothermic and hyperthermic conditions) and its influence on histological and behavioural outcomes following cerebral ischemia. Brain Pathol 2000, 10:145-152.

90. Maier CM, Ahern K, Cheng ML, Lee JE, Yenari MA, Steinberg GK: Optimal depth and duration of mild hypothermia in a focal model of transient cerebral ischemia: effects on neurologic outcome, infarct size, apoptosis, and inflammation. Stroke 1998, 29:2171-2180.

91. Doerfler A, Schwab S, Hoffmann TT, Engelhorn T, Forsting M: Combination of decompressive craniectomy and mild hypothermia ameliorates infarction volume after permanent focal ischemia in rats. Stroke 2001, 32:2675-2681.

92. Krieger DW, De Georgia MA, Abou-Chebl A, Andrefsky JC, Sila CA, Katzan IL, Mayberg MR, Furlan AJ: Cooling for acute ischemic brain damage (COOL-AID): an open pilot study of induced hypothermia in acute ischemic stroke. Stroke 2001, 32:1847-1854

93. De Georgia MA, Krieger DW, Abou-Chebl A, Devlin TG, Jauss M, Davis SM, Koroshetz WJ, Rordorf G, Warach S: Cooling for acute ischemic brain damage (COOL-AID): a feasibility trial of endovascular cooling. Neurology 2004, 63:312-317.

94. Milhaud D, Thouvenot E, Heroum C, Escuret E: Prolonged moderate hypothermia in massive hemispheric infarction: clinical experience. J Neurosurg Anesthesiol 2005, 17:49-53.

95. Schwab S, Schwarz S, Spranger M, Keller E, Bertram M, Hacke $\mathrm{W}$ : Moderate hypothermia in the treatment of patients with severe middle cerebral artery infarction. Stroke 1998, 29: 2461-2466.

96. Schwab S, Spranger M, Aschoff A, Steiner T, Hacke W: Brain temperature monitoring and modulation in patients with severe MCA infarction. Neurology 1997, 48:762-767.

97. Schwab S, Schwarz S, Aschoff A, Keller E, Hacke W: Moderate hypothermia and brain temperature in patients with severe middle cerebral artery infarction. Acta Neurochir (Wien) 1998, 71 Suppl:131-134.

98. Stone JG, Goodman RR, Baker KZ, Baker CJ, Solomon RA: Direct intraoperative measurement of human brain temperature. Neurosurgery 1997, 41:20-24.

99. Georgiadis D, Schwarz S, Kollmar R, Schwab S: Endovascular cooling for moderate hypothermia in patients with acute stroke: first results of a novel approach. Stroke 2001, 32: 2550-2553.

100. Steiner T, Friede T, Aschoff A, Schellinger PD, Schwab S, Hacke W: Effect and feasibility of controlled rewarming after moderate hypothermia in stroke patients with malignant infarction of the middle cerebral artery. Stroke 2001, 32:2833-2835.

101. Wang $H$, Olivero W, Lanzino G, Elkins W, Rose J, Honings D, Rodde M, Burnham J, Wang D: Rapid and selective cerebral hypothermia achieved using a cooling helmet. J Neurosurg 2004, 100:272-277.

102. Gulumna KZ, Hemmen TM, Olsen SE, Rapp KS, Lyden PD: A trial of therapeutic hypothermia via endovascular approach in awake patients with acute ischemic stroke: methodology. Acad Emerg Med 2006, 13:820-827.

103. Greco T: Post-traumatic thrombosis of the carotid artery [in Italian]. Arch Ital Chir 1935, 39:757-784.

104. Wirtz CR, Steiner T, Aschoff A, Schwab S, Schnippering $H$, Steiner $\mathrm{HH}$, Hacke W, Kunze S: Hemicraniectomy with dural augmentation in medically uncontrollable hemispheric infarction. Neurosurgery Focus 1997, 2:1-4.
105. Forsting $M$, Reith W, Schaebitz WR, Heiland S, von Kummer R, Hacke W, Sartor K: Decompressive craniectomy for cerebral infarction: an experimental study in rats. Stroke 1995, 26:259264.

106. Engelhorn T, Doerfler A, Kastrup A, Beaulieu C, de Crespigny A, Forsting M, Moseley ME, Faraci FM: Decompressive craniectomy, reperfusion, or a combination for early treatment of acute 'malignant' cerebral hemispheric stroke in rats: potential mechanisms studied by MRI. Stroke 1999, 30:1456-1463.

107. Hofmeijer J, Schepers J, Veldhuis WB, Nicolay K, Kappelle LJ, Bar PR, van der Worp HB: Delayed decompressive surgery increases apparent diffusion coefficient and improves periinfarct perfusion in rats with space-occupying cerebral infarction. Stroke 2004, 35:1476-1481.

108. Jaeger M, Soehle M, Meixensberger J: Improvement of brain tissue oxygen and intracranial pressure during and after surgical decompression for diffuse brain oedema and space occupying infarction. Acta Neurochir (Wien) 2005, 95 Suppl: 117-118.

109. Schwab S, Steiner T, Aschoff A, Schwarz S, Steiner HH, Jansen $\mathrm{O}$, Hacke W: Early hemicranectomy in patients with complete middle cerebral artery infarction. Stroke 1998, 29:1888-1893.

110. Mori K, Ishimaru S, Maeda M: Unco-parahippocampectomy for direct surgical treatment of downward transtentorial herniation. Acta Neurochir (Wien) 1998, 140:1239-1244.

111. Mori K, Nakao Y, Yamamoto T, Maeda M: Early external decompressive craniectomy with duroplasty improves functional recovery in patients with massive hemispheric embolic infarction: timing and indication of decompressive surgery for malignant cerebral infarction. Surg Neurol 2004, 62:420-429.

112. Robertson SC, Lennarson P, Hasan DM, Traynelis VC: Clinical course and surgical management of massive cerebral infarction. Neurosurgery 2004, 55:55-62.

113. Wagner S, Schnippering H, Aschoff A, Koziol JA, Schwab S, Steiner T: Suboptimum hemicraniectomy as a cause of additional cerebral lesions in patients with malignant infarction of the middle cerebral artery. J Neurosurg 2001, 94:693-696.

114. Holtkamp M, Buchheim K, Unterberg A, Hoffmann O, Schielke E, Weber JR, Masuhr F: Hemicraniectomy in elderly patients with space occupying media infarction: improved survival but poor functional outcome. J Neurol Neurosurg Psych 2001, 70:226228.

115. Cho DY, Chen TC, Lee HC: Ultra-early decompressive craniectomy for malignant middle cerebral artery infarction. Surg Neuro/ 2003, 60:227-232.

116. Maramattom BV, Bahn MM, Wijdicks EMF. Which patient fares worse after early deterioration due to swelling from hemispheric stroke? Neurology 2004, 63:2142-2145.

117. Wang KW, Chang WN, Ho JT, Chang HW, Lui CC, Cheng MH, Hung KS, Wang HC, Tsai NW, Sun TK, et al.: Factors predictive of fatality in massive middle cerebral artery territory infarction and clinical experience of decompressive hemicraniectomy. Eur J Neurol 2006, 13:765-771.

118. Delashaw JB, Broaddus WC, Kassell NF, Haley EC, Pendleton GA, Vollmer DG, Maggio WW, Grady MS: Treatment of right hemispheric cerebral infarction by hemicraniectomy. Stroke 1990, 21:874-881.

119. Steiger HJ: Outcome of acute supratentorial cerebral infarction in patients under 60. Development of a prognostic grading system. Acta Neurochir (Wien) 1991, 111:73-79.

120. Mori K, Aoki A, Yamamoto T, Horinaka N, Maeda M: Aggressive decompressive surgery in patients with massive hemispheric embolic cerebral infarction associated with severe brain swelling. Acta Neurochir (Wien) 2001, 143:483-492.

121. Kuroki K, Taguchi H, Sumida M, Yukawa O, Marukami T, Onda J, Eguchi K: Decompressive craniectomy for massive infarction of middle cerebral artery territory [abstract]. No Shinkei Geka 2001, 29:831-835.

122. Yang X, Yao Y, Hu W, Li G, Xu J, Zhao X, Liu W: Is decompressive craniectomy for malignant middle cerebral artery infarction of any worth? J Zheijang Univ SC/ 2005, 6B:644-649.

123. Gupta R, Connolly ES, Mayer S, Elkind MS: Hemicraniectomy for massive middle cerebral artery territory infarction. A systematic review. Stroke 2004, 35:539-543.

124. Georgiadis D, Schwarz S, Aschoff A, Schwab S: Hemicraniectomy and moderate hypothermia in patients with severe ischemic stroke. Stroke 2002, 33:1584-1588. 
125. Els T, Oehm E, Voigt S, Klisch J, Hetzel A, Kassubek J: Safety and therapeutical benefit of hemicraniectomy combined with mild hypothermia in comparison with hemicraniectomy alone in patients with malignant ischemic stroke. Cerebrovasc Dis 2006, 21:79-85.

126. Kastrau F, Wolter M, Huber W, Block F: Recovery from aphasia after hemicraniectomy for infarction of the speech-dominant hemisphere. Stroke 2005, 36:825-829.

127. Uhl E, Kreth FW, Elias B, Goldammer A, Hempelmann RG, Liefner M, Nowak G, Oertel M, Schmieder K, Schneider HH: Outcome and prognostic factors of hemicraniectomy for space occupying cerebral infarction. J Neurol Neurosurg Psych 2004, 75: 270-274.

128. Harscher S, Reichart R, Terborg C, Hagemann G, Kalff R, Witte OW: Outcome after decompressive craniectomy in patients with severe ischemic stroke. Acta Neurochir (Wien) 2006, 148:31-37.

129. Kilincer C, Asil T, Utku U, Hamamcioglu MK, Turgut N, Hicdonmez T, Simsek O, Ekuklu G, Cobanoglu S: Factors affecting the outcome of decompressive craniectomy for large hemispheric infarctions: a prospective cohort study. Acta Neurochir (Wien) 2005, 147:587-594.

130. Rabinstein AA, Mueller-Kronast N, Maramottom BV, Zazulia AR, Bamlet WR, Diringer MN, Wijdicks EFM: Factors predicting prognosis after decompressive hemicraniectomy for hemispheric infarction. Neurology 2006, 76:891-893.

131. Frank J, Krieger D, Chyatte D, Cancian S: Hemicraniectomy and durotomy upon deterioration from massive hemispheric infarction: a proposed multicenter, prospective, randomized study. Stroke 1999, 30:243.

132. [No authors listed]: Major ongoing stroke trials. Stroke 2006, 37:e18-26.

133. Vahedi K, Hofmeijer J, Juettler E, Vicaut E, George B, Algra A, Amelink GJ, Schmiedek P, Schwab S, Rothwell PM, et al., for the DECIMAL, DESTINY, and HAMLET investigators: Early decompressive surgery in malignant middle cerebral artery infarction: a pooled analysis of three randomised controlled trials. Lancet Neurology 2007, 6:215-222.

134. Schwab S, Georgiadis D, Berrouschot J, Schellinger PD, Graffagnino C, Mayer SA: Feasibility and safety of moderate hypothermia after massive hemispheric infarction. Stroke 2001, 32:2033-2035.

135. Rankin J: Cerebral vascular accidents in people over the age of 60: II. Prognosis. Scott Med J 1957, 2:200-215.

136. Mahoney GI, Barthel DW: Functional evaluation. The Barthel Index. MD State Med J 1965, 14:61-65.

137. Morley NC, Berge E, Cruz-Flores S, Whittle IR: Surgical decompression for cerebral oedema in acute ischaemic stroke. Cochrane Database Syst Rev 2002:CD003435. 